\title{
Conversion of biogas from anaerobic digestion to single cell protein and bio-methanol: mechanism, microorganisms and key factors - A review
}

\author{
Reza Salehi ${ }^{1^{\dagger}}$, Sumate Chaiprapat ${ }^{2,3}$ \\ ${ }^{1}$ Independent Researcher, 3495 Saint-Dominique, Montreal, Quebec H2X 2X5, Canada \\ ${ }^{2}$ Department of Civil and Environmental Engineering, Faculty of Engineering, Prince of Songkla University, Hat Yai, Songkhla, 90110, Thailand \\ ${ }^{3}$ PSU Energy Systems Research Institute, Research and Development Office, Prince of Songkla University, Hat Yai, Songkhla 90110, Thailand
}

\begin{abstract}
Biogas is a mixture of mainly $\mathrm{CH}_{4}$ and $\mathrm{CO}_{2}$, which can be generated from anaerobic digestion of organic materials. The use of biogas is mostly limited to thermal energy and electricity generation. However, the abundance of cheap shale gas and solar energy could drive out biogas for such applications in the near future. Hence, alternative applications of biogas have recently received great attention among researchers across the globe. This review, for the first time, discusses the feasibility of the bioconversion of biogas to value-added products, including single cell protein as animal feed supplement, and methanol that is an important building block in the chemical industries. Mechanisms of the process, microorgnisms involved and key parameters affecting their efficiency are discussed in detail. Some future research needs are suggested in order to deepen our understanding of these biochemical processes.
\end{abstract}

Keywords: Anaerobic digestion, Biogas bioconversion, Bio-methanol, Single cell protein

\section{Introduction}

Biogas, a promising renewable energy source, is generated during anaerobic digestion $(\mathrm{AD})$ process where different microbial species degrade organic materials (OMs) in the absence of oxygen [1, 2]. A wide range of waste types can be used as feedstock for biogas production. For instance, sludge from water resource recovery facilities (WRRFs) [3], agricultural residues [4-7], paper waste [8, 9], food waste [10], and livestock manure [11, 12]. The yield and composition of biogas from $\mathrm{AD}$ depend largely upon the type of feedstock and operating conditions [13, 14]. The composition of biogas originating from $\mathrm{AD}$ process fed with different types of feedstocks is listed in Table 1 [15-32].

It can be seen from Table 1 that $\mathrm{CH}_{4}$ and $\mathrm{CO}_{2}$ (two largest contributing greenhouse gases) are the main constituents of biogas. Therefore, biogas release to atmosphere must be avoided due to the adverse environmental impact. Biogas generally contains hydrogen sulfide $\left(\mathrm{H}_{2} \mathrm{~S}\right)$ from a trace amount to a concentration as high as 80,000 ppmv depending on the feedstock's sulfur content [17].
When $\mathrm{H}_{2} \mathrm{~S}$ and water vapor co-exist, biochemical reactions by thiobacilli rapidly produce sulfuric acid [33, 34] that is highly corrosive and causes the metal equipment and concrete structure to wear down. The combustion of biogas containing $\mathrm{H}_{2} \mathrm{~S}$ leads to the formation of sulfur dioxide $\left(\mathrm{SO}_{2}\right)$. The product $\mathrm{SO}_{2}$ can chemically react with moisture in the atmosphere to form sulfuric acid resulting in acid rain [35]. Therefore, prior to biogas utilization, an appropriate pre-treatment technique considering the economic and environmental benefits is required. Biogas desulfurization techniques biological and physicochemical - have been widely reported in literatures [36-38]; they are beyond the scope of this review.

Biogas, after pre-treatment (cleaned mainly for the content of $\mathrm{H}_{2} \mathrm{~S}$ and water vapor), is nowadays used in internal combustion engines (ICEs) and boilers for electricity and thermal energy generation $[39,40]$. In addition, it can be upgraded to bio-methane, for the purpose of injection into the natural gas network [41, 42], or can also be utilized as a vehicular fuel [43, 44].

The incentives to utilize biogas for the aforementioned applications might weaken in the near future. Shale oil and gas are expected
This is an Open Access article distributed under the terms of the Creative Commons Attribution Non-Commercial License (http://creativecommons.org/licenses/by-nc/3.0/) which permits unrestricted non-commercial use, distribution, and reproduction in any medium, provided the original work is properly cited.

Copyright (C) 2022 Korean Society of Environmental Engineers
Received March 01, 2021 Accepted June 16, 2021

${ }^{\dagger}$ Corresponding author

E-mail: reza.salehi@polymtl.ca

Tel: +1 4388896591

ORCID: 0000-0003-1416-173X 
Table 1. Composition of Biogas Produced from AD of Different Type of Feedstock

\begin{tabular}{|c|c|c|c|c|}
\hline \multirow{2}{*}{ Feedstock } & \multicolumn{3}{|c|}{ Biogas composition } & \multirow{2}{*}{ Reference } \\
\hline & $\mathrm{CH}_{4}$ (vol.\%) & $\mathrm{CO}_{2}$ (vol.\%) & $\mathrm{H}_{2} \mathrm{~S}$ (ppmv) & \\
\hline \multirow[t]{7}{*}{ Sewage sludge } & $65-75$ & 20-35 & $<5,800$ & {$[15]$} \\
\hline & $58-75$ & $20-40$ & 0-63 & {$[16]$} \\
\hline & $65-75$ & $20-35$ & $0-10,000$ & {$[17]$} \\
\hline & $60-75$ & $19-33$ & $670-2,660$ & {$[18]$} \\
\hline & $61-65$ & $36-38$ & traces & [19] \\
\hline & $55-65$ & $35-45$ & $0-63$ & {$[20]$} \\
\hline & 58 & $34-39$ & $24-63$ & {$[21,22]$} \\
\hline \multirow[t]{5}{*}{ Agricultural waste } & $54-74$ & $22-40$ & traces & {$[23]$} \\
\hline & $50-80$ & $30-50$ & 7,000 & {$[24]$} \\
\hline & $51-53$ & $44-48$ & $83-405$ & {$[25]$} \\
\hline & $60-75$ & $19-33$ & $2,160-7,200$ & {$[26]$} \\
\hline & $45-75$ & $25-55$ & 10-180 & {$[16]$} \\
\hline Industrial waste & $50-70$ & $30-50$ & 8,000 & {$[24]$} \\
\hline \multirow[t]{2}{*}{ Livestock manure } & $50-77$ & $30-50$ & $0-80,000$ & [17] \\
\hline & 64 & 34 & 500 & {$[27]$} \\
\hline \multirow[t]{2}{*}{ Agro-food waste } & 68 & 26 & 288 & {$[26]$} \\
\hline & $50-75$ & 26 & $<21,500$ & {$[28]$} \\
\hline \multirow[t]{2}{*}{ Food waste } & $51-59$ & $35-43$ & n.r. & [29] \\
\hline & $61-64$ & $33-37$ & $0-323$ & {$[30]$} \\
\hline \multirow[t]{2}{*}{ Household waste } & $50-60$ & $34-38$ & $72-648$ & {$[26]$} \\
\hline & 60 & 33 & n.r. & {$[31]$} \\
\hline Slaughterhouse waste & 79 & $18-20$ & n.r. & {$[32]$} \\
\hline
\end{tabular}

$\mathrm{AD}$ : anaerobic digestion; ppmv: part per million by volume; n.r.; not reported.

to be plentiful and cheap due to the advanced extraction technologies and fast expansion of technically recoverable shale reserves worldwide [45, 46]. In addition, the use of biogas for electricity generation faces competition with other renewable sources such as solar and wind. The unit cost of solar panels (called photovoltaic (PV) modules) and equipment has declined so dramatically over the last decade [47] that is now cheap enough and yet much more efficient to outcompete biogas for the purpose of electricity generation. According to Kost et al. [48], in Germany, the largest mature European market of biogas for electricity generation, the levelized cost of energy (LCOE) for biogas-based power generating plants (specific investments of 2,000-4,000 €/kW) ranges between $0.10 € / \mathrm{kWh}(7,000$ full load hours $(\mathrm{FLH})$ per year) and $0.15 € / \mathrm{kWh}$ (5,000 FLH per year), while the LCOE of large scale PV rooftop power plants with a global horizontal irradiation (GHI) of 950-1,300 $\mathrm{kWh} / \mathrm{m}^{2} \mathrm{a}$ ranges between $0.05 € / \mathrm{kWh}$ and $0.08 € / \mathrm{kWh}$. In meanwhile, the LCOE of onshore wind power plants $(1,800-3,200$ FLH per year) lies in the range of $0.04 € / \mathrm{kWh}$ and $0.08 € / \mathrm{kWh}$. The LCOE is a measure of the average revenue per unit of electricity generated by a given generating plant over its lifetime. The International Renewable Energy Agency (IRENA) published a technical report in November 2019, which shows that the LCOE of solar PV plants has decreased significantly over years, 77\% since 2010, reaching $\$ 0.08 / \mathrm{kWh}$ in 2018. Further drop in the LCOE of solar PV plants is expected over the next decades, reaching $(\$ 0.08-\$ 0.02) / \mathrm{kWh}$ and (\$0.05-\$0.01)/kWh by 2030 and 2050, respectively [47]. For these reasons, novel uses of biogas have drawn great attention in recent years. This review focuses on existing studies related to the utilization of biogas for producing single cell protein as animal feed supplement, and methanol as an important building block in the chemical industries. Yet, to the best of the authors' knowledge, the lack of such a review paper is evident in literature.

This review is organized into two sections. The first section deals with single-cell protein production, and the second is concerned with bio-methanol production. In each respective section, the main mechanism together with the microorganisms involved and the key process parameters are systematically presented, which could point to the research gaps where further studies should be directed.

\section{Biogas Conversion to Single-cell Protein}

The rapidly growing world population (9-10 billion people by 2050) $[49,50]$ will lead to an increase in demand on protein-rich foods, which rely mainly on animal proteins [51, 52]. The higher demands on animal-based food, the higher the production of agricultural crops (e.g., soybean meal) for animal feeds [53]. The crops production is often energy-intensive, has a high water/land footprint, and generates large quantities of residues [54]. In addition, in case where the application of fertilizers is essential for better crop yield, their excessive use contributes toward eutrophication, which causes 
detrimental impact on our ecosystem [55]. Furthermore, the crop yield depends on soil characteristics and the weather conditions [56] that limit the productivity and cultivatable plant species. In recent years, scientific community has focused on developing innovative approaches to supply animal feeds. In this context, microbial-based protein production processes have caught remarkable attention because they do not necessarily exhibit any of the above-mentioned drawbacks [54, 57, 58]. Microbial protein - popularly termed single cell protein (SCP) [59] - refers to protein derived from the dried cells of bacteria, fungi, algae, or yeasts [60]. In dealing with SCP production, different sources have been utilized as feedstock. For instance, edible sugars (Quorn ${ }^{\mathrm{TM}}$, Marlow Foods Ltd, UK), natural gas [60-62], and agro-industrial wastes [63-65]. However, there are some challenges associated with the use of these feedstocks for SCP production: i) edible sugars-based SCP production process may be economically less viable, ii) the direct utilization of agro-industrial wastes may lead to accumulation of heavy metals in the SCP, which might hinder the consumption of this bio-product [66], and iii) natural gas-based SCP production processes are becoming less attractive because of reliance on the unsustainable fossil resources.

In order to eliminate the risk of accumulation of toxic substances in the SCP and to ensure the sustainability and economic viability of SCP production process, biogas could be a promising and attractive feedstock. This section aims to represent the proof-of-concept for biogas conversion to SCP.

\subsection{Choice of Microorganisms and Culture Mediums}

Various microorganisms possess the capability of utilizing $\mathrm{CH}_{4}$ and/or $\mathrm{CO}_{2}$ in biogas as carbon source while assimilating nitrogen from a cultivation medium leading to SCP production. These microorganisms include:

i) Aerobic methane-oxidizing bacteria (MOB), so-called methanotrophs, which utilize $\mathrm{CH}_{4}$ as both carbon source and energy source. Methanotrophic bacteria rely on $\mathrm{O}_{2}$ to oxidize $\mathrm{CH}_{4}$ into $\mathrm{CO}_{2}$ while building up their new cellular material [67]. Examples of the most popular methanotrophic genera (and species, if applicable) for biogas-based SCP synthesis are Methylocystis [57], Methylomonas [57, 68, 69], Methylophilus [68, 69], Rurimicrobium [68], Comamonadaceae [69], Methylophilales [70], Methylococcales [70], Methylococcus capsulatus [53, 71], Methylomicrobium buryatense [72], Methylocystis parvus [73], Methylomonas methanica [74], Methylomicrobium alcaliphilum 20Z(R) [75, 76], and Methylocapsa acidiphila DSM 13967 [77]. It is worth noting that several methanotrophic genera have been reported to be capable of $\mathrm{CO}_{2}$ fixation, which make them suitable candidates to grow on biogas; for instance, Methylococcus, Methylocaldum, and Methyloferula [67].

ii) Autotrophic hydrogen-oxidizing bacteria (HOB), sometimes called Knallgas bacteria [58], which utilize $\mathrm{O}_{2}$ as an electron acceptor and $\mathrm{H}_{2}$ as an electron donor, and fix $\mathrm{CO}_{2}$ to biomass while assimilating ammonia nitrogen [78, 79]. According to the literatures, the following HOB genera (and species, if applicable) demonstrated to be capable of producing SCP. These include Hydrogenomonas [80], Aquaspirillum [81], Alcaligenes eutrophus Z1 and Ralstonia eutropha B5786 [82], Pseudomonas [83], Paracoccus denitrificans Y5, and Paracoccus versutus D6 [78]. However, HOB can hardly be a suitable candidate for SCP production from biogas because hydrogen generated as an intermediate in acidogenesis stage during $\mathrm{AD}$ is quickly converted to methane by methanogenic archaea. It can exist only if methanogenesis stage is intentionally inhibited for bio-hydrogen production [84], which is not commercially practiced today.

iii) Algae, which use $\mathrm{CO}_{2}$ in the presence of sunlight (or artificial light) as energy source leading to $\mathrm{O}_{2}$ and biomass production [85]. Several potent algal species recently used for SCP synthesis include Chlorella sorokiniana [53, 71, 75], Synechococcus PCC 7002 [75, 76], Scenedesmus [73], and Arthrosipira platensis [72].

The most frequently used mediums to cultivate the SCP producers (methanotrophs, HOB, algae) are synthetic nitrogen-rich sources such as ammonium mineral salts (AMS) [66, 68, 71], nitrate mineral salts (NMS) [77], Zarrouk's medium [72], A-plus medium and P-medium [75, 76]. However, such culture mediums are expensive [59]. Hence, in the recent years, application of waste streams as nitrogen source for microorganisms' growth has shown a good promise with zero or negative cost when adopted to replace high-energy intensive process such as activated sludge. These waste streams include supernatant of the anaerobically digested sludge/bio-waste (ADs) $[68,70,71]$, and food industry wastewater (FIWW), for instance, the effluent of a potato processing plant [53]. The ADs/FIWW can be considered as a promising alternative to the synthetic mediums for SCP production making the process economically more viable.

A challenging issue associated with the use of $\mathrm{ADs}$ as a culture medium for SCP production is that they contain high ammonium concentration [86, 87], e.g., 1,000-3,000 $\mathrm{mg} \mathrm{NH}_{4}{ }^{+}-\mathrm{N} / \mathrm{L}$ [85], which should be diluted to meet the desired ammonium concentration (below $150 \mathrm{mg} \mathrm{NH}_{4}{ }^{+} \mathrm{N} / \mathrm{L}$ ) [66, 71]. This implies that a large volume of freshwater for the dilution process is required while going to produce SCP at a large scale. This is not realistic because freshwater is becoming a scarce resource worldwide. In order to address this limitation, the secondary clarifier water (SCW) from the WRRFs could be used instead without affecting the microbial growth [71].

The gravitationally settled ADs, diluted with SCW, can be directly used as a culture medium without requiring pre-treatment, e.g., filtration or autoclaving, which present an inhibitive cost to this application. An example is the study of Roberts et al. [71], who investigated biogas conversion into microbial biomass using a co-culture of Chlorella sorokiniana and Methylococcus capsulatus grown separately on the gravitationally settled ADs, pre-treated $\mathrm{ADs}$ and the sterilized AMS medium (as the control). According to their findings, the growth profile of the co-culture grown in the gravitationally settled $\mathrm{ADs}$ was comparable to those obtained using either the pre-treated ADs or the sterilized AMS medium. However, prior to the use of FIWW as a culture medium, it should be subjected to centrifugation and autoclaving (to ensure neither solids nor indigenous bacteria are present) that make full scale SCP production infeasible [53]. In this context, ultrafiltration could be instead applied. According to the study of Podevin et al. [88], an ultrafiltered IWW stream was successfully utilized as a culture medium for algal growth in a full-scale reactor.

\subsection{Production Process}

The production of SCP from biogas takes place in enclosed bio- 
reactors where the selected microorganisms, in the presence of biogas, are grown in a sterile medium containing the essential nutrient for their growth. The generated biomass is then processed for the protein extraction. Fig. 1(a) illustrates biogas-based SCP production process driven by methanotrophs, which metabolize $\mathrm{CH}_{4}$ in the biogas. Such a process is less attractive in converting biogas into SCP because $\mathrm{CO}_{2}$ in the biogas remain unused; in other words, $\mathrm{CO}_{2}$ emission to air persists. This is a problematic issue because $\mathrm{CO}_{2}$ is a major contributor to global warming. In addition, since biogas and $\mathrm{O}_{2}$ are directly bubbled in the bioreactor culture medium, an explosive mixture in the bioreactor headspace may occur [53, 57].
In order to enable both $\mathrm{CH}_{4}$ and $\mathrm{CO}_{2}$ contribution to the production of SCP, a possible solution is the use of methanotrophs co-cultivated with autotrophic $\mathrm{HOB}$ in a single stage system [66] (Fig. 1(b)). This process relies on $\mathrm{O}_{2}$ and $\mathrm{H}_{2}$ gases, which are expensive resources [54] as they are usually generated by electrolysis of water that is an energy-intensive method [58, 89]. In addition, the risk of an explosion still appears to be a challenge for the safety of such a process [58].

A highly promising alternative process to the above mentioned methanotroph- and (methanotroph-HOB)-based SCP production processes is the use of a consortium of algae and methanotrophs in a single stage phototrophic reactor (Fig. 1(c)). In this process,
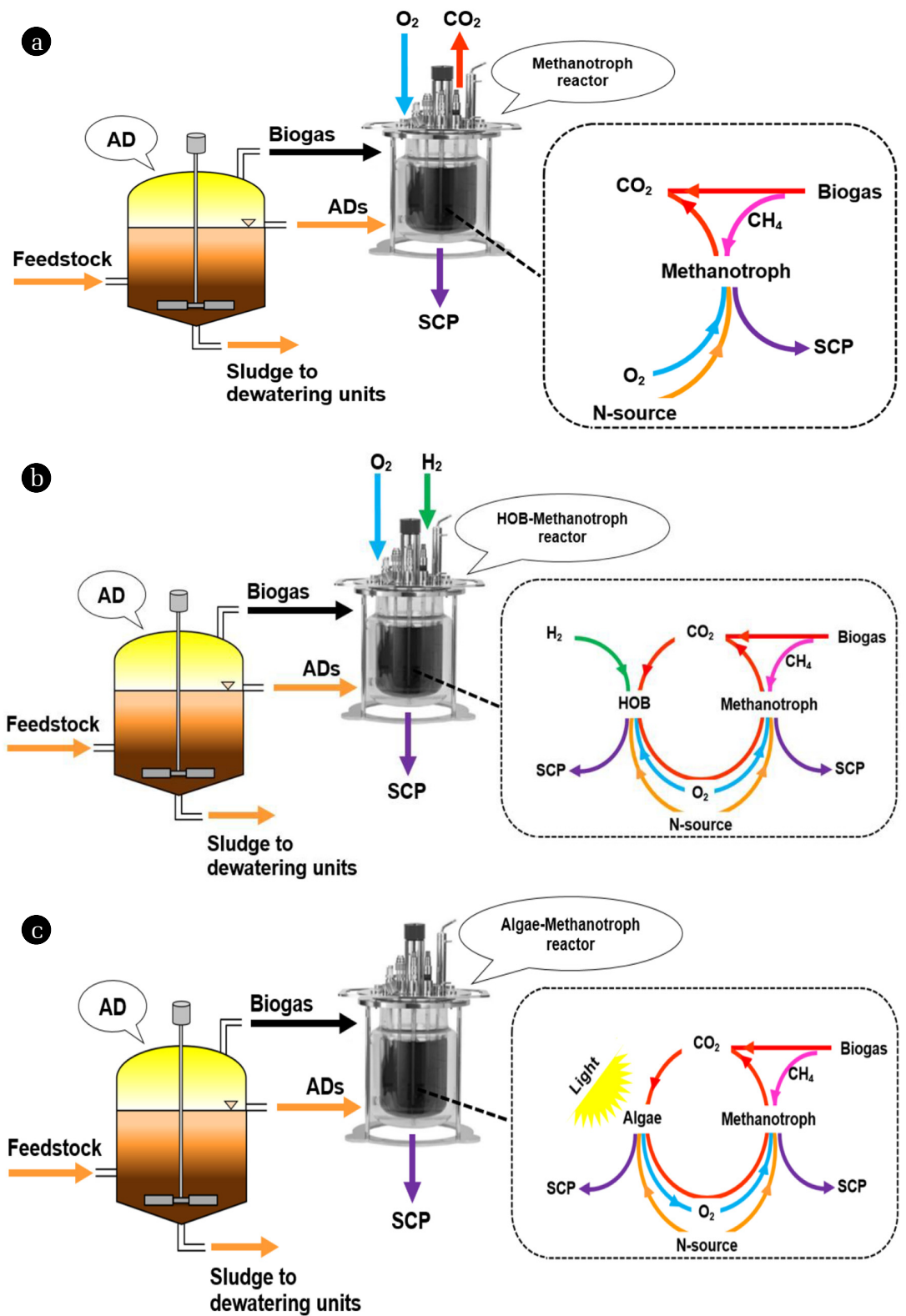

Fig. 1. Schematic illustration of biogas-based SCP production processes using (a) methanotroph, (b) autotrophic HOB-methanotroph consortia, and (c) algae-methanotroph consortia. 
Table 2. Recent Studies of Biogas-based SCP Produced Using Various Microbial Cultures

\begin{tabular}{|c|c|c|c|c|c|c|}
\hline \multirow[b]{2}{*}{ Microbial culture } & \multicolumn{2}{|c|}{ Culture medium } & \multicolumn{2}{|r|}{ Biogas } & \multirow{2}{*}{$\begin{array}{c}\text { Biomass SCP } \\
\left(\% \mathbf{w} \mathbf{w}^{-1}\right. \\
\text { DCW })\end{array}$} & \multirow[b]{2}{*}{ Reference } \\
\hline & Source & $\begin{array}{l}\mathrm{NH}_{4}-\mathrm{N} \text { conc. } \\
\left(\mathrm{mg} \mathrm{L}^{-1}\right)\end{array}$ & Source & $\begin{array}{c}\text { Composition } \\
\left(\% \mathbf{v} \mathbf{v}^{-1}\right)\end{array}$ & & \\
\hline M.capsulatus & $\mathrm{IWW}^{1}$ & 19 & Synth. & $\left(60 \% \mathrm{CH}_{4} ; 10 \% \mathrm{CO}_{2} ; 30 \% \mathrm{O}_{2}\right)^{2}$ & 53 & {$[53]$} \\
\hline HOB-MOB & $\mathrm{AMS}^{3}$ & 131 & Real $^{4}$ & $\left(52 \% \mathrm{CH}_{4} ; 44 \% \mathrm{CO}_{2} ; 3 \% \mathrm{~N}_{2}, 0.8 \% \mathrm{O}_{2}\right)^{5}$ & $61 \pm 8$ & [66] \\
\hline Mixed $\mathrm{MOB}^{6}$ & dAMS & 28 & $\operatorname{Real}^{7}$ & n.r. & $46 \pm 2$ & {$[68]$} \\
\hline Mixed $\mathrm{MOB}^{8}$ & $\mathrm{ADs}^{9}$ & 28 & $\operatorname{Real}^{7}$ & n.r. & $41 \pm 2$ & \\
\hline C.sorokiniana-M.capsulatus & $\mathrm{ADs}^{10}$ & 120 & Synth. & $70 \% \mathrm{CH}_{4} ; 30 \% \mathrm{CO}_{2}$ & $43 \pm 4$ & {$[71]$} \\
\hline
\end{tabular}

${ }^{1}$ centrifuged-autoclaved

${ }^{2}$ gas composition at the end of C.sorokiniana cultivation test using a synthetic biogas $\left(60 \% \mathrm{CH}_{4}\right.$ and $\left.40 \% \mathrm{CO}_{2}\right)$

${ }^{3}$ supplemented with vitamin solution of DSMZ medium 81

${ }^{4}$ originated from a mesophilic $\mathrm{AD}$ fed with agricultural wastes (pumpkin and pig manure)

${ }^{5}$ averaged of 30 measurements on a daily basis

${ }^{6}$ dominated by $34.80 \%$ Methylophilus sp.1, 12.64\% Rurimicrobium sp., and 10.50\% Methylomonas sp.1

${ }^{7}$ a thermophilic $\mathrm{AD}$ fed with a mixture of primary and secondary sludge

${ }^{8}$ dominated by $56.26 \%$ Methylomonas sp.1, and $24.60 \%$ Methylophilus sp. 1

${ }^{9}$ centrifugated-filtered-pasteurized-diluted supernatant of a thermophilic AD fed with a mixture of primary and secondary sludge

${ }^{10}$ gravitationally settled-diluted supernatant of a mesophilic sludge-based AD

the methanotrophs use the in situ generated $\mathrm{O}_{2}$ by algae to convert $\mathrm{CH}_{4}$ into biomass while generating $\mathrm{CO}_{2}$ that is subsequently fixed by the algae. Such a process offers several advantages over the methanotrophs and methanotrophs-HOB processes: i) it does not require an external $\mathrm{O}_{2}$ supply, ii) $\mathrm{CH}_{4}$ and $\mathrm{CO}_{2}$ in the biogas can be simultaneously converted to biomass, and iii) the risk of an explosion is eliminated [53, 71, 72].

Table 2 summarizes the results of the existing studies related to the biogas-based SCP production by means of methanotrophs, autotrophic HOB-methanotroph consortia, and algae-methanotroph consortia.

As seen in Table 2, the protein content of the biomass is within the range of $41-61 \%$ on a dry cell weight (DCW) basis, which is superior to soybean meal $(35-44 \%)[54,58,90]$ that is the most common vegetable-based protein for livestock feed, and comparable with fishmeal (55-65\%) [90, 91]. Therefore, SCP products can replace such costly conventional protein sources for aquaculture/animal feed supplement. A number of researchers successfully tested the SCP products in feed trials with various fish species and mono-gastric animal such as pigs, broiler chicken, mink and fox [61, 92, 93]. However, as of today, there exists a number of issues making the SCP products unsuitable for the use in human diets: i) in the case of obtaining SCPs from bacterial-based biomass, they may contain nucleic acid, notably ribonucleic acid (RNA), as high as $8-16 \%$ [82, 94, 95], which is too high for human consumption. The maximum safe limit of RNA for a person is $2 \mathrm{~g} / \mathrm{d}$. Intaking RNA more than $2 \mathrm{~g} / \mathrm{d}$ may pose serious health problems such as gout and kidney-stone [58, 62, 96]. This is because purine $\left(\mathrm{C}_{5} \mathrm{H}_{4} \mathrm{~N}_{4}\right)$ compounds - generated from breaking down of RNA - are degraded to uric acid, which are then accumulated in the body due to the lack of uricase enzyme. It is worth noting that RNA-rich SCP products as feed for ruminants and short-lived mono-gastric animals does not cause serious problem [60, 97], ii) algal-based SCP products, although having relatively low nucleic acid content (3-8\%) [60], their rigid cellulosic cell wall (about $10 \%$ of DCW) is indigestible by humans due to the lake of cellulose degrading enzymes [95], iii) SCP may carry heavy metals - when waste streams are used as the cultivation medium - that can cause detrimental effects on human health, and iv) SCP may contain toxin compounds if the microbial culture and the process conditions are not properly controlled. Rudravaram et al. [74] reported that a methane-oxidizing bacterium Methylomonas methanica, which is capable of storing high levels of protein, produces endotoxins at certain environmental conditions.

Taking into account the above-mentioned issues, if SCP products are going to be marketed for direct consumption as human food, it will have to go thru a long journey of the regulatory approval process. First, they must undergo a number of proper treatments to disrupt the cellulosic cellular wall and reduce nucleic acid content to a level that meets the guidelines for the use as food or food supplements, without affecting the quantity and quality of the amino acids. Second, a series of costly and time-consuming toxicological tests are required to ensure the SCP products are truly safe for human consumption. These tests involve short-term studies for acute toxicity and long-term chronic toxicity, where laboratory/farm animals are fed with normal diets incorporated with different amounts of SCP. In this context, animal species such as mice, rats, rabbits, and guinea pigs can be served as animal models. The duration of the toxicological tests ranges from few weeks to few years (equal to the lifespan of the animal under study). After that period, hematological, biochemical and pathological examinations are performed to check possible adverse effects of SCP on the tested animal organs. The more specific toxicity tests include carcinogenicity, multiple generation, mutagenicity, teratogenicity, and sensitization [98]. Shacklady [99] has reported an extensive range of toxicological test results on "Toprina", which is a product of Candida lipolytica. Useful information concerning the safety evaluation of SCP products is available in [100-104].

Testing the toxicity of SCP products in animal models might not be adequate to identify all possible adverse effects in human. 
For instance, allergenic responses may not be detectable through animal trials. Therefore, once SCP products are demonstrated to be free of toxic compounds, and not to leave unpleasant residues in the tested animal tissues, they have to be subjected to clinical tolerance trials [104-106]. The toxicity tests for Quorn ${ }^{\mathrm{TM}}$ Myco-protein (Marlow Foods Ltd, UK) lasted 16 years, with many more years needed to obtain approval for sale outside the UK [107].

It is worth mentioning that, in order to perform toxicological tests on SCP, a considerable amount of SCP must be produced. As an example, Imperial Chemical Industries (ICI) "Pruteen" factory in Billingham, England, utilized approximately 500 tons of Pruteen in feeding 200,000 animals (7 different species) at a cost of approximately \$ 6 million to carry out toxicological studies on Pruteen [98]; Pruteen was derived from the methanol-assimilating bacterium Methylophilus methylotrophus.

\subsection{Effect of $\mathrm{H}_{2} \mathrm{~S}$ in Raw Biogas on SCP Production}

Raw biogas usually contains 500-1,000 ppmv $\mathrm{H}_{2} \mathrm{~S}$ [77], sometimes as high as 10,000-26,000 ppmv depending on the feedstocks used for biogas production [108, 109], which can adversely affect biogas conversion to SCP. Tsapekos et al. [69] operated a lab-scale aerobic fermenter fed with either raw biogas or pure $\mathrm{CH}_{4}$. The fermenter was enriched with a mixed methanotrophic culture grown in the liquid digestate from a municipal biowaste digester. They observed that biomass production using raw biogas $\left(\mathrm{CH}_{4} 61 \%, \mathrm{CO}_{2} 39 \%\right.$ and $\mathrm{H}_{2} \mathrm{~S} 913$ ppmv) was $38 \%$ lower than that of obtained using pure $\mathrm{CH}_{4}$. Xu et al. [77] studied SCP production from $\mathrm{H}_{2} \mathrm{~S}$-rich synthetic biogas using acid-tolerant Methylocapsa acidiphila DSM 13967, belonging to type II methanotrophs Alphaproteobacteria, grown in NMS medium. The focus of their study was to investigate how $\mathrm{H}_{2} \mathrm{~S}$ would influence the SCP productivity. Their results demonstrated that the presence of $\mathrm{H}_{2} \mathrm{~S}$ in the biogas could significantly affect the biomass quality. Protein content in the biomass of Methylocapsa acidiphila grown on $\mathrm{H}_{2} \mathrm{~S}$-free biogas sample was approximately $59 \%$ DCW. It decreased to about $40 \%$ and $28 \%$ when the biogas supplied with 165 ppmv and 725 ppmv $\mathrm{H}_{2} \mathrm{~S}$, respectively. Based on the results of Tsapekos et al. [69], and Xu et al. [77], it is of high importance to desulfurize raw biogas prior to use for SCP production. More updated and comprehensive information on biogas desulfurization can be found in the studies of Khoshnevisan et al. [37], and Okoro and Sun [110].

\subsection{Future Research Needs}

Current developments and improvement of the biogas-based SCP production processes are noteworthy. However, despite large amount of research devoted to such processes, there remains two major aspects, given below, which need to be taken into account in future research.

1) In biogas-based SCP production processes, $\mathrm{CO}_{2}$ is dissolved in the medium (and dissociated into bicarbonate), which results in lowering the medium $\mathrm{pH}$ into the acidic zone [70]. Hence, caustic addition would be required to neutralize the medium $\mathrm{pH}$ that leads to an increase in chemical costs. Therefore, exploring acid-tolerant methanotrophic strains for converting biogas to SCP should come into focus as a future research effort. This could make the SCP production process economically more attractive because $\mathrm{pH}$ neu- tralization could no longer be essential. In addition, acidic wastewater streams could be used as growth medium or nitrogen source without an external alkaline addition.

2) Utilization of genetically modified microorganisms (GMM) in SCP production from biogas has not been previously reported. The GMM technique could improve the safety of SCP products because the genes contributing to toxin production can be removed or inactivated. It could also enhance the quality of SCP products in terms of amino acids and vitamins. Therefore, future study might look into biogas conversion to SCP by means of GMMs, specifically when the SCP products are intended for food applications.

\section{Biogas Bioconversion to Methanol}

Methanol, known as methyl alcohol, is the simplest alcohol with chemical formula $\mathrm{CH}_{3} \mathrm{OH}$ that is often abbreviated as $\mathrm{MeOH}$. It has a wide range of applications in chemical industries. For instance, it is used in the synthesis of organic compounds such as acetic acid (HAc), dimethyl ether (DME), methyl-tert-butyl ether (MTBE), mono-methylamines (MMA), dimethyl terephthalate (DMT), olefins, etc. [111-113]. In addition, $\mathrm{MeOH}$ is considered as a cleaner fuel with a lower risk of flammability and higher octane number (a quantitative measure of the knock resistance of a fuel) compared to gasoline [114]. Moreover, it is a theoretical carbon source for biological denitrification (DN) process [115], and hence, $\mathrm{MeOH}$ synthesis from biogas generated in anaerobic digesters of WRRFs can result in a reduction in operational cost of the wastewater treatment processes.

Today, the most developed technologies for the production of $\mathrm{MeOH}$ rely on the catalytic thermochemical reactions. However, such technologies incur a high operating cost because of the need for high pressure (up to $150 \mathrm{~atm}$ ) and high temperature $\left(200^{\circ} \mathrm{C}-1,000^{\circ} \mathrm{C}\right)[116]$. A cost-effective alternative route to the thermochemical pathways for $\mathrm{MeOH}$ production is the biological processes. The bio-MeOH production process driven by the action of microorganisms can be operated at ambient conditions [117]. In this direction, the utilization of biogas as the feedstock draws a great attention. The biological production of biogas-based $\mathrm{MeOH}$ offers an environmental advantage because it can replace the fossil-based $\mathrm{MeOH}$, and thus fight global warming. Besides, it requires much less energy.

\subsection{Insight into the Mechanism}

Biological conversion of biogas into $\mathrm{MeOH}$ is carried out by aerobic methanotrophs via sequential reactions (Fig. 2). The reactions are catalyzed by different enzymes, including methane monooxygenases (MMOs), methanol dehydrogenase (MDH), formaldehyde dehydrogenases $\left(\mathrm{F}_{\text {ald }} \mathrm{DH}\right)$, and formate dehydrogenases $\left.\left(\mathrm{F}_{\text {ate }} \mathrm{DH}\right)\right)$ [118, 119, 121].

There are two forms of MMO: i) particulate MMO (pMMO) that is a membrane-bound enzyme, and ii) soluble MMO (sMMO), which is a cytoplasmic enzyme. The expression of MMOs is largely dependent on copper concentration in the growth medium. pMMO contains copper active sites, and has higher affinity for $\mathrm{CH}_{4}$ compared to sMMO. The pMMO is active when copper concentration exceeds 


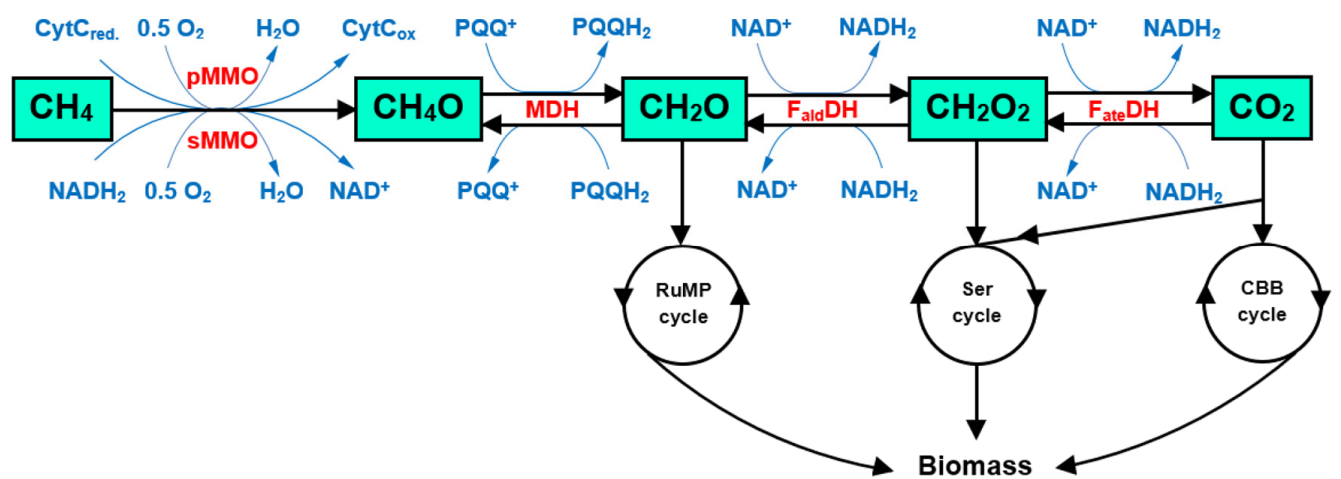

Fig. 2. Simplified pathway for the conversion of biogas (a mixture of $\mathrm{CH}_{4}$ and $\mathrm{CO}_{2}$ ) to methanol $\left(\mathrm{CH}_{4} \mathrm{O}\right.$ ) by methanotrophs (adapted from Fei et al. [118]; Xin et al. [119]). Key enzymes are in red. Abbreviations: CytC, cytochrome complex; $F_{\text {ald }} D H$, formaldehyde dehydrogenase; $\mathrm{F}_{\text {ate }} \mathrm{DH}$, formate dehydrogenase; $\mathrm{MDH}$, methanol dehydrogenase, $\mathrm{NADH}_{2}$, reduced form of $\mathrm{NAD}$ (nicotinamide adenine dinucleotide); pMMO, particulate methane monooxygenase; $\mathrm{PQQH}_{2}$, reduced form of $\mathrm{PQQ}$ (pyrroloquinoline quinol); RuMP, ribulose monophosphate; Ser, serin; sMMO, soluble methane monooxygenase; CBB, Calvin-Benson-Bassham. (For detailed information on RuMP, Ser and CBB cycles, the reader is referred to Fei et al. [118], and Khmelenina et al. [120]).

one $\mu \mathrm{mol}$ per one gram dry weight of cells, whereas sMMO activity is only present under limited-copper conditions [122-124].

The primary reaction involved in the conversion of biogas to $\mathrm{MeOH}$ is $\mathrm{CH}_{4}$ oxidation driven by the action of MMOs. The MMOs utilize reducing equivalents such as cytochrome complex (CytC) or $\mathrm{NADH}_{2}$ (reduced form of NAD; nicotinamide adenine dinucleotide; $\mathrm{H}$ stands for hydrogen), depending on whether pMMO or sMMO is used to cleavage the O-O bonds in molecular oxygen $\left(\mathrm{O}_{2}\right)$ into monovalent oxygen atoms. One of the oxygen atoms is reduced to produce $\mathrm{H}_{2} \mathrm{O}$, and the other is incorporated into $\mathrm{CH}_{4}$ leading to $\mathrm{MeOH}$ formation. The product $\mathrm{MeOH}$ is then oxidized to formaldehyde $\left(\mathrm{CH}_{2} \mathrm{O}\right)$ by $\mathrm{MDH}$, a pyrroloquinoline quinone (PQQ)-dependent enzyme. Formaldehyde is further oxidized to formate $\left(\mathrm{CH}_{2} \mathrm{O}_{2}\right)$ and then to $\mathrm{CO}_{2}$ through the action of $\mathrm{F}_{\text {ald }} \mathrm{DH}$ and $\mathrm{F}_{\text {ate }} \mathrm{DH}$, respectively. The oxidation of $\mathrm{MeOH}$ to $\mathrm{CO}_{2}$ generates reducing equivalents (six reducing equivalents per molecule of $\mathrm{MeOH}$ ), which are utilized by MMOs to sustain $\mathrm{CH}_{4}$ conversion to $\mathrm{MeOH}[118,125,126]$. The $\mathrm{CO}_{2}$ can be reduced to $\mathrm{MeOH}$ via the reverse oxidation of $\mathrm{MeOH}$ if sufficient amount of reducing equivalent is supplied [121].

The formaldehyde, formate and $\mathrm{CO}_{2}$ can be assimilated into microbial biomass depending upon the phylogeny and physiology of methanotrophs. Group I methanotrophs (Gammaproteobacteria) employ ribulose monophosphate (RuMP) cycle to assimilate carbon, whereas Group II methanotrophs (Alphaproteobacteria) and Group III methanotrophs (Verrucomicrobial) utilize serine (Ser) and Calvin-Benson-Bassham (CBB) cycles, respectively [122, 123, 127]. The detailed information on RuMP, Ser and CBB cycles can be found in the studies of Fei et al. [118], and Khmelenina et al. [120].

\subsection{The Use of MDH Activity Inhibitors}

A major issue associated with biogas bioconversion to $\mathrm{MeOH}$ is further oxidation of $\mathrm{MeOH}$, which leads to lower extracellular $\mathrm{MeOH}$ accumulation [128]. In order not to allow $\mathrm{MeOH}$ to be oxidized, $\mathrm{MDH}$ metabolic activity must be suppressed. However, this ap- proach creates a problem because $\mathrm{NADH}$ needed to sustain MMOs activity is depleted and cannot be regenerated. In other words, $\mathrm{CH}_{4}$ will no longer be oxidized. To overcome this limitation, external electron donors, generally formate, are required [126, 129, 130].

Kim et al. [115] have shown the feasibility of using $\mathrm{NaCl}$ as an $\mathrm{MDH}$ activity inhibitor for improving $\mathrm{MeOH}$ production from raw biogas (composed of $68.9 \% \mathrm{CH}_{4}$ ) by means of mixed methanotroph species grown in NMS medium $\left(30^{\circ} \mathrm{C}, \mathrm{pH} 6.8\right.$, incubation period $48 \mathrm{~h}$; biogas-to-air ratio 3.4:1 $\mathrm{v} \mathrm{v}^{-1}$ ). Their results indicated that supplementation of the medium with $60 \mathrm{mM} \mathrm{NaCl}$ and 40 $\mathrm{mM}$ sodium formate yielded $6.4 \mathrm{mM} \mathrm{MeOH}$, which was $83 \%$ higher than that of obtained from the control (without $\mathrm{NaCl}$ and sodium formate). In the study of Patel et al. [128], $\mathrm{MeOH}$ accumulation using methanotrophs Methyloferula stellata (DSM 22108) and Methylomonas methanica (DSM 25384) was found to be $0.09 \mathrm{mM}$ and $0.13 \mathrm{mM}$, respectively, when $100 \mathrm{mM}$ phosphate buffer was supplied as an individual $\mathrm{MDH}$ inhibitor. Using $100 \mathrm{mM}$ phosphate buffer together with $50 \mathrm{mM} \mathrm{MgCl} 2$ as a combined $\mathrm{MDH}$ inhibitor, $\mathrm{MeOH}$ production increased to $0.29 \mathrm{mM}$ and $0.48 \mathrm{mM}$, respectively. The addition of $100 \mathrm{mM}$ formate significantly improved $\mathrm{MeOH}$ production by 9.1 - and 8.0 -fold, to $2.64 \mathrm{mM}$ and $3.86 \mathrm{mM}$, by Methyloferula stellata, and Methylomonas methanica, respectively. Note that $\mathrm{CH}_{4}(30 \%)$ was utilized as a feed in this study under $30^{\circ} \mathrm{C}$, pH 7.0, incubation period $24 \mathrm{~h}$, and inoculum conc. 3,000 mg DCW $\mathrm{L}^{-1}$.

\subsection{Key Parameters Affecting $\mathrm{MeOH}$ Production}

\subsubsection{Temperature and $\mathrm{pH}$}

Biogas conversion to $\mathrm{MeOH}$, driven by methanotrophs, is a temperature and $\mathrm{pH}$ dependent process because the physiological behavior and growth of methanotrophs are greatly influenced by the medium temperature and $\mathrm{pH}[118,131,132]$. Methanotrophic species, e.g., Methylocaldum sp. 14B [133], Methylosinus sporium DSMZ 17706 [134], Methylomonas methanica DSM 25384 and Methylocella tundra DSMZ 15673 [128, 135], Methylocystis bryophila DSM 21852 [136], Methylomicrobium album ATCC 33003 and Methyloferula 
stellate DSM 22108 [137], Methylosinus trichosporium IMV 3011 [119], which have been used for $\mathrm{MeOH}$ production, are mesophilic with an optimum temperature range of $30-37^{\circ} \mathrm{C}$.

Zhang et al. [125] reported that no significant growth of Methylocaldum gracile SAD2 was observed at temperatures $20^{\circ} \mathrm{C}$, $25^{\circ} \mathrm{C}$ or $45^{\circ} \mathrm{C}$. However, Su et al. [138], for the first time, reported $\mathrm{MeOH}$ production at relatively higher temperatures using a consortium of methanotrophs isolated from corn stover-based $\mathrm{AD}$ digestate. The consortium (dominated by $87.2 \%$ Methylocaldum and $7.0 \%$ Agrobacterium), grew effectively on raw biogas (72\% $\mathrm{CH}_{4}, 26 \% \mathrm{CO}_{2}, 1.7 \% \mathrm{~N}_{2}$, and $0.3 \% \mathrm{O}_{2}$ ) within a temperature range of $30-55^{\circ} \mathrm{C}$. A maximum $\mathrm{MeOH}$ production of $10.3 \mathrm{mM}$ was obtained at $47^{\circ} \mathrm{C}$ (pH 6.8, biogas-to-air ratio $1: 1 \mathrm{v} \mathrm{v}^{-1}$, inoculum conc. 2,300 mg DCW $\mathrm{L}^{-1}$, incubation period 144h). They also evaluated the influence of $\mathrm{pH}$ on $\mathrm{CH}_{4}$ oxidation by the consortium at $47^{\circ} \mathrm{C}$. According to their results, at $\mathrm{pH}$ levels from 5.5 to 7.5, the rate of $\mathrm{CH}_{4}$ oxidation was found to be high and consistent (91\%). The consortium grew more stably at $\mathrm{pH}$ value of 6.8 with a maximum cell yield of $0.31 \mathrm{~g}$ cells $/ \mathrm{g} \mathrm{CH}_{4}$. When the $\mathrm{pH}$ was 5.0 , only $7 \%$ of the $\mathrm{CH}_{4}$ content was oxidized. Yoo et al. [139] reported that the oxidation of $\mathrm{CH}_{4}$ using Methylosinus sporium was about $26 \%$ at $\mathrm{pH}$ value of 5.0 , which was $48 \%$ lower than that of obtained at $\mathrm{pH}$ value of $7.0\left(35^{\circ} \mathrm{C}\right.$, biogas-to-air ratio $2: 3 \mathrm{v} \mathrm{v}^{-1}$ where biogas composed of $50 \% \mathrm{CH}_{4}$ and $50 \% \mathrm{CO}_{2}$ ). These imply that proton activity in the medium has significant impact to MMOs activity of the consortium, which should be kept in near neutral environment.

\subsubsection{Biogas-to-air ratio}

Before delivering biogas to methanotrophs, it should be mixed with air (or pure $\mathrm{O}_{2}$ ) because methanotrophs need molecular oxygen to oxidize $\mathrm{CH}_{4}$ [67]. Patel et al. [117] studied $\mathrm{MeOH}$ production using Methylosinus sporium DSMZ 17706 grown in NMS medium under an atmospheric pressure of raw biogas $\left(62 \% \mathrm{CH}_{4}\right)$, which was diluted with air to maintain $\mathrm{CH}_{4}$ concentration in the range of $10-50 \% \mathrm{v} \mathrm{v}^{-1}$. According to their findings, $\mathrm{CH}_{4}$ concentration of $20 \%$ (corresponded to a biogas-to-air ratio of 2.1:1 $\mathrm{v} \mathrm{v}^{-1}$ ) resulted in the highest $\mathrm{MeOH}$ production of $4.63 \mathrm{mM}\left(30^{\circ} \mathrm{C}, \mathrm{pH} 7.0\right.$, inoculum conc. 3,000 mg DCW L ${ }^{-1}, 48 \mathrm{~h}$ incubation). Su et al. [138] conducted a series of experiments to optimize biogas-to-air ratio for $\mathrm{MeOH}$ production using a mixed culture of methanotrophs dominated by Methylocaldum (87.2\%). Different biogas-to-air ratios $\left(1: 6,1: 4,1: 2,1: 1\right.$, and $\left.1: 2 \mathrm{v} \mathrm{v}^{-1}\right)$ were tested with raw biogas (72.0\% $\mathrm{CH}_{4}, 26.0 \% \mathrm{CO}_{2}, 1.7 \% \mathrm{~N}_{2}$, and $0.3 \% \mathrm{O}_{2}$ ) originated from a food waste digester. They found that the biogas-to-air ratio of $1: 1 \mathrm{v} \mathrm{v}^{-1}$ resulted in the highest level of $\mathrm{CH}_{4}$-to-MeOH conversion $\left(0.47 \mathrm{~mol} \mathrm{~mol}^{-1}\right)$ at a temperature and $\mathrm{pH}$ of $47^{\circ} \mathrm{C}$ and 6.8 , respectively (after $168 \mathrm{~h}$ incubation). In a recent report, Henard et al. [140] determined the growth of three methanotrophs strains Methylomicrobium alcaliphilum 20ZR, Methylosinus trichosporium OB3b, and Methylococcus capsulatus Bath with a simulated biogas $\left(60 \% \mathrm{CH}_{4}, 40 \% \mathrm{CO}_{2}\right)$ at different biogas-to-air ratios (1:17, 1:7, 1:3, and 1:1). The growth of all strains positively correlated to the biogas-to-air ratio with an optimal growth at biogas-to-air ratio of 1:3-1:1 $\mathrm{v} \mathrm{v}^{-1}$. This could be due to higher $\mathrm{CH}_{4}$ concentration in the headspace, leading to an increase in $\mathrm{CH}_{4}$ availability in the culture medium.

\subsection{3. $\mathrm{H}_{2} \mathrm{~S}$ Presence in biogas}

One of the main challenges associated with the processes dealing with $\mathrm{MeOH}$ production from biogas is the inhibition of methanotrophs by $\mathrm{H}_{2} \mathrm{~S}[117,126] . \mathrm{H}_{2} \mathrm{~S}$ is inevitably present in biogas as mentioned earlier. In the study of Eun-Hee et al. [141], $\mathrm{CH}_{4}$ oxidation capacity of methanotroph Methylocystis sp. was inhibited approximately $48 \%$ in the presence of 200 ppmv $\mathrm{H}_{2} \mathrm{~S}$. Caceres et al. [142] showed that the growth of Methylomicrobium album (ATCC 33003) and Methylocystis sp. (ATCC 49242) grown on a mixture of $\mathrm{CH}_{4}$

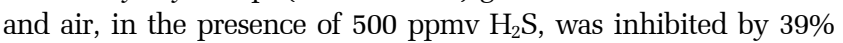
and $47 \%$, respectively. It appears from these results that the need to desulfurize biogas is definitely required prior to its utilization for cell cultivation and $\mathrm{MeOH}$ production. To keep costs low, biogas desulfurization should be avoided. Thus, robust methanotrophic strains that can tolerate relatively high concentration of $\mathrm{H}_{2} \mathrm{~S}$ are desirable. Zhang et al. [125], for the first time, isolated a high $\mathrm{H}_{2} \mathrm{~S}$-tolerant methanotrophic strain (Methylocaldum gracile SAD2) from digestate of a mesophilic digester of expired dog food to evaluate its performance in producing $\mathrm{MeOH}$ using raw biogas. The strain $\mathrm{SAD} 2 \mathrm{had}$ the capability of producing $8.6 \mathrm{mM} \mathrm{MeOH}$ when the raw biogas-to-air mixture $\left(1: 2 \mathrm{v} \mathrm{v}^{-1}\right)$ contained about $520 \mathrm{ppm}_{2} \mathrm{~S}$ under $37^{\circ} \mathrm{C}$, $\mathrm{pH}$ 6.8-7.5, and $48 \mathrm{~h}$ incubation in NMS medium. In addition, the growth of this strain was inhibited by only $17 \%$. These results imply that a more $\mathrm{H}_{2} \mathrm{~S}$ tolerant strain (other than SAD2) could be identified that would become effective for $\mathrm{MeOH}$ production from $\mathrm{H}_{2} \mathrm{~S}$-rich biogas without requiring biogas desulfurization.

\subsection{Enhancement of $\mathrm{MeOH}$ Production Using Cell Immobilization Technique}

Cell immobilization can be preformed by different methods, including i) adsorption that is driven by electrostatic forces on a solid support, ii) covalent linkage between the support and the cell membrane, and iii) encapsulation where the cells are entrapped inside a porous material. The main advantage of immobilized cell systems is that the loss of cells to the surrounding medium and ultimately off the reactor can be avoided or minimized, while diffusing of nutrient and metabolites are allowed into the densely populated immobilized matrix [143, 144].

Patel et al. [117] investigated $\mathrm{MeOH}$ production from raw biogas composed of $20 \% \mathrm{CH}_{4}$ (diluted with air) by the methanotrophs Methylosinus sporium DSMZ 17706 immobilized on different types of supports such as Amberlite and Duolite A7 ion-exchange resins, and Chitosan. Based on their findings, $\mathrm{MeOH}$ productivity was significantly improved by the immobilized Methylosinus sporium compared to their suspended culture. After incubation for 120 $\mathrm{h}$ at $30^{\circ} \mathrm{C}$ and a $\mathrm{pH}$ value of 7.0 , a maximum yield of $5.22 \mathrm{mM}$ $\mathrm{MeOH}$ was observed, which was approximately $72 \%$ higher than that obtained from the free suspended culture. Patel et al. [136] later evaluated $\mathrm{MeOH}$ production using covalently immobilized Methylocystis bryophila (DSM 21852) with a synthetic gas feed (30\% $\mathrm{CH}_{4}, 15 \% \mathrm{CO}_{2}$, and 55\% air) under repeated batch condition (eight reuse cycles of $24 \mathrm{~h}$ incubations). Their results demonstrated that the immobilized cells yielded a remarkably higher cumulative $\mathrm{MeOH}$ concentration $(25.8 \mathrm{mM})$ than that of the free cells (15.50 $\mathrm{mM}$ ). Table 3 summarizes the results of recent studies directed 
Table 3. Results of Recent Studies Related to the Use of Immobilized Cell Techniques for MeOH Production from Simulated/raw Biogas by Various Strains of Methanotrophs

\begin{tabular}{|c|c|c|c|c|c|c|c|}
\hline Strains $^{\text {a }}$ & Feed $\left(\% \mathbf{v}^{-1}\right)$ & Technique & Support & $\begin{array}{l}\text { Incubation } \\
\text { period (h) }\end{array}$ & $\begin{array}{c}\mathrm{pH} / \mathrm{T} \\
\left({ }^{\circ} \mathrm{C}\right)\end{array}$ & $\begin{array}{l}\text { MeOH prod. } \\
(\mathrm{mM})\end{array}$ & Reference \\
\hline \multirow[t]{9}{*}{ M. album ATCC 33003} & $30 \% \mathrm{CH}_{4}, 15 \% \mathrm{CO}_{2}$ & Free cells & $\mathrm{n} / \mathrm{a}$ & 72 & $7.0 / 30$ & 3.8 & [137] \\
\hline & & Encapsulation & Alginate & & & 4.1 & \\
\hline & & & PVA & & & 4.6 & \\
\hline & $30 \% \mathrm{CH}_{4}, 7.5 \% \mathrm{CO}_{2}$ & Free cell & $\mathrm{n} / \mathrm{a}$ & & $7.0 / 30$ & 3.9 & {$[145]$} \\
\hline & & Covalent & cmChitosan $^{\mathrm{e}}$ & & & 5.0 & \\
\hline & & Free cell & $\mathrm{n} / \mathrm{a}$ & $24^{\mathrm{f}}$ & & $12.5^{\mathrm{g}}$ & \\
\hline & & Covalent & cmChitosan $^{\mathrm{e}}$ & & & $24.0^{\mathrm{g}}$ & \\
\hline & $\begin{array}{c}\left(30 \% \mathrm{CH}_{4}, 16 \% \mathrm{CO}_{2}\right. \\
\left.\quad 46 \mathrm{ppm} \mathrm{H}_{2} \mathrm{~S}\right)^{\mathrm{c}}\end{array}$ & Free cell & $\mathrm{n} / \mathrm{a}$ & 72 & & 4.4 & \\
\hline & & Covalent & cmChitosan $^{\mathrm{e}}$ & & & 6.7 & \\
\hline \multirow[t]{3}{*}{ M. stellate DSM 22108} & $30 \% \mathrm{CH}_{4}, 15 \% \mathrm{CO}_{2}$ & Free cells & $\mathrm{n} / \mathrm{a}$ & & & 3.3 & {$[137]$} \\
\hline & & Encapsulation & Alginate & & & 3.6 & \\
\hline & & & PVA & & & 3.9 & \\
\hline \multirow[t]{2}{*}{ M. bryophila DSM 21852} & & Free cells & $\mathrm{n} / \mathrm{a}$ & & & 4.7 & {$[136]$} \\
\hline & & Covalent & Chitosan & & & 5.3 & \\
\hline \multirow[t]{9}{*}{ See note ${ }^{b}$} & & Free cells & $\mathrm{n} / \mathrm{a}$ & 72 & & 4.9 & [128] \\
\hline & & Encapsulation & Alginate & & & 5.0 & \\
\hline & & & Silica gel & & & 5.9 & \\
\hline & & Free cells & $\mathrm{n} / \mathrm{a}$ & $24^{\mathrm{f}}$ & & $19.5^{\mathrm{g}}$ & \\
\hline & & Encapsulation & Alginate & & & $25.7^{\mathrm{g}}$ & \\
\hline & & & Silica gel & & & $32.0^{\mathrm{g}}$ & \\
\hline & $\begin{array}{l}\left(32 \% \mathrm{CH}_{4}, 18 \% \mathrm{CO}_{2}\right. \\
\left.\quad 650 \mathrm{ppm} \mathrm{H}_{2} \mathrm{~S}\right)^{\mathrm{d}}\end{array}$ & Free cells & $\mathrm{n} / \mathrm{a}$ & 48 & & 4.6 & \\
\hline & & Encapsulation & Alginate & & & 4.7 & \\
\hline & & & Silica gel & & & 5.7 & \\
\hline \multirow[t]{2}{*}{ M. sporium DSMZ 17706} & $30 \% \mathrm{CH}_{4}, 15 \% \mathrm{CO}_{2}, 5 \% \mathrm{H}_{2}$ & Free cells & $\mathrm{n} / \mathrm{a}$ & & $6.8 / 30$ & 4.9 & [146] \\
\hline & & Covalent & Chitosan & & & 6.1 & \\
\hline
\end{tabular}

Notes: ${ }^{\mathrm{a}} 3,000 \mathrm{mg}$ DCW L-1; ${ }^{\mathrm{b}}$ co-culture of $M$. tundrae DSMZ 15673 and M.methanica DSM 25384; 'rice straw-based biogas (65.4\% CH, $34.6 \% \mathrm{CO}_{2}$ and $\left.100 \mathrm{ppm} \mathrm{H}_{2} \mathrm{~S}\right)$, which was diluted in a 1.18:1.00 ( $\left.\mathrm{v} \mathrm{v}^{-1}\right)$ ratio with air; ${ }^{\mathrm{d}}$ municipal waste-based biogas $\left(63.4 \% \mathrm{CH}_{4}\right.$, $35.6 \% \mathrm{CO}_{2}$ and $\left.1,300 \mathrm{ppm} \mathrm{H}_{2} \mathrm{~S}\right)$, which was diluted in a 1:1 ( $\left.\mathrm{v} \mathrm{v}^{-1}\right)$ ratio with air; ${ }^{e}$ chemically modified Chitosan with APTES followed by GLA; 'repeated batch test (8 cycles of reuse; each cycle was incubated for $24 \mathrm{~h}$ ); ${ }^{\mathrm{g}}$ Cumulative MeOH production (mM).

towards the use of immobilized cell techniques for $\mathrm{MeOH}$ production from simulated or raw biogas by various strains of methanotrophs. These studies clearly suggest that cell immobilized processes are superior to the suspended process for biogas conversion to $\mathrm{MeOH}$, nothing that the efficiency can be further optimized if the operating paremeters and environmental conditions are properly controlled.

\section{Conclusions}

Overview of the current state of bioconversion studies of biogas to single cell protein (SCP) and methanol (MeOH) are summarized. These are by far the most feasible lucrative means to up-value the biogas which is today in some areas are in excess or of low value. Biogas can be converted to SCP by methanotrophic bacteria alone, or in combination with autotrophic hydrogen oxidizing bac- teria (HOB) or algae in a single-stage process. Among which, the process driven by the algae-methanotroph coculture is more economically viable. The product from algal-bacterial SCP is rich in protein, up to $60 \%$ on dry basis, and has a great potential as a substitute for the costly traditional protein sources for animal and human. Another approach to valorize biogas is bioconversion to $\mathrm{MeOH}$. It relies on the activity of methane monooxygenase (MMO) in methanotrophs. Most of the methanotrophic species used are mesophilic with optimum growth at neutral $\mathrm{pH}$. To obtain $\mathrm{MeOH}$ from biogas by methanotrophs, it is necessary to inhibit methanol dehydrogenase $(\mathrm{MDH})$, and supply an external electron donor, mainly formate, to sustain MMO metabolic activity. The bioconversion rate of biogas to $\mathrm{MeOH}$ is primarily affected by types of inhibitors, biogas-to-air ratio, and $\mathrm{H}_{2} \mathrm{~S}$ in biogas. Cell immobilization technique and $\mathrm{H}_{2} \mathrm{~S}$ tolerant strains are of major research interest in improving $\mathrm{MeOH}$ production efficiency. 


\section{Acknowledgment}

The authors would like to thank the support from Biogas and Biorefinery Laboratory at the Faculty of Engineering and PSU Energy Systems Research Institute, Prince of Songkla University, Thailand.

\section{Author Contributions}

R.S. (Ph.D. Independent Researcher) wrote the original draft, and did visualization. S.C. (Professor) reviewed and edited the article.

\section{References}

1. Sawyerr N, Trois C, Workneh T, Okudoh V. An overview of biogas production: Fundamentals, applications and future research. Int. J. Energy Econ. Policy 2019;9:105-116.

2. Kiran EU, Stamatelatou K, Antonopoulou G, Lyberatos G. Production of biogas via anaerobic digestion. In: Luque $\mathrm{R}$, Campelo J, Clark J, eds. Handbook of Biofuels Production (Processes and Technologies). Cambridge: Woodhead Publishing; 2016. p. 266-304.

3. Sapmaz S, Kilicaslan I. Biogas production from sewage sludge as a distributed energy generation element: A nationwide case study for Turkey. Environ Res. Technol. 2019;2:93-97.

4. Abdullah A, Ahmed A, Akhter P, et al. Potential for sustainable utilisation of agricultural residues for bioenergy production in Pakistan: An overview. J. Cleaner Prod. 2021;287:125047.

5. Miskat MI, Ahmed A, Chowdhury H, et al. Assessing the Theoretical Prospects of Bioethanol Production as a Biofuel from Agricultural Residues in Bangladesh: A Review. Sustainability 2020;12:8583.

6. Corre WJ, Conijn JG. Biogas production and digestate utilisation from agricultural residues [HYSOL project, deliverable $\mathrm{n}^{\circ}$ : 6.2.1]. Wageningen: Wageningen University; 2016.

7. Nitsos C, Matsakas L, Triantafyllidis K, Rova U, Christakopoulos, P. Evaluation of mediterranean agricultural residues as a potential feedstock for the production of biogas via anaerobic fermentation. BioMed Res. Int. 2015;2015:171635.

8. Rodriguez C, Alaswad A, El-Hassan Z, Olabi AG. Waste paper and macroalgae co-digestion effect on methane production. Energy 2018;154:119-125.

9. Ofoefule AU, Nwankwo JI, Ibeto CN. Biogas production from paper waste and its blend with cow dung. Adv. Appl. Sci. Res. 2010;1:1-8.

10. Mirmohamadsadeghi S, Karimi K, Tabatabaei M, Aghbashlo M. Biogas production from food wastes: A review on recent developments and future perspectives. Bioresour. Technol. Rep. 2019;7:100202.

11. Chowdhury T, Chowdhury H, Hossain N, et al. Latest advancements on livestock waste management and biogas production: Bangladesh's perspective. J. Clean. Prod. 2020;272:122818.

12. Noorollahi Y, Kheirrouz M, Farabi Asl H, Yousefi H, Hajinezhad A. Biogas production potential from livestock manure in Iran. Renew. Sust. Energy Rev. 2015;50:748-754.
13. Kulichkova GI, Ivanova TS, Köttner M, et al. Plant feedstocks and their Biogas Production Potentials. Open Agric. J. 2020;14:219-234.

14. Nsair A, Cinar SO, Alassali A, Qdais HA, Kuchta K. Operational parameters of biogas plants: A review and evaluation study. Energies 2020;13:3761.

15. Kuo J. Air quality issues related to using biogas from anaerobic digestion of food waste [report CEC-500-2015-037]. California: California State University; 2015.

16. Gao Y, Jiang J, Meng Y, Yan F, Aihemaiti A. A review of recent developments in hydrogen production via biogas dry Reforming. Energy Convers. Manage. 2018;171:133-155.

17. Ramirez M, Gomez J, Cantero D. Biogas: sources, purification and uses. In: Sharma UC, Kumar S, Prasad R, eds. Hydrogen and Other Technologies. Houston: Studium Press LLC; 2015. p. 296-323.

18. Hagen A, Winiwarter A, Langnickel H, Johnson G. SOFC Operation with Real Biogas. Fuel Cells 2017;17:854-861.

19. Rasi S, Veijanen A, Rintala J. Trace compounds of biogas from different biogas production plants. Energy 2007;32:1375-1380.

20. Chouhan K, Sinha S, Kumar S, Kumar S. Utilization of biogas from different substrates for SOFC feed via steam reforming: Thermodynamic and exergy analyses. J. Environ. Chem. Eng. 2019;7:103018.

21. Spiegel RJ, Preston JL. Test results for fuel cell operation on anaerobic digester gas. J. Power Sources 2000;86:283-288.

22. Spiegel RJ, Preston JL. Technical assessment of fuel cell operation on anaerobic digester gas at the Yonkers, NY, wastewater treatment plant. Waste Manage. 2003;23:709-717.

23. Onthong U, Juntarachat N. Evaluation of biogas production from raw and processed agricultural wastes. Energy Procedia 2017;138:205-210.

24. Chen XY, Vinh-Thang H, Ramirez AA, Rodrigue D, Kaliaguine S. Membrane gas separation technologies for biogas upgrading. RSC Adv. 2015;5:24399.

25. Benato A, Macor A. Italian biogas plants: Trend, subsidies, cost, biogas composition and engine emissions. Energies 2019;12:979.

26. Yentekakis IV, Goula G. Biogas management: Advanced utilization for production of renewable energy and added-value chemicals. Front. Environ. Sci. 2017;5:7.

27. Mushtaq K, Zaidi AA, Askari SJ. Design and performance analysis of floating dome type portable biogas plant for domestic use in Pakistan. Sust. Energy Technol. Assess. 2016;14:21-25.

28. Allegue LB, Hinge J. Biogas and bio-syngas upgrading [report]. Taastrup: Danish Technological Institute; 2012.

29. Ikpe AE, Imonitie DI, Ndon AIE. Investigation of biogas energy derivation from anaerobic digestion of different local food wastes in Nigeria. Acad. Platform J. Eng. Sci. 2019;7:332-340.

30. Kuo J, Dow J. Biogas production from anaerobic digestion of food waste and relevant air quality implications. J. Air Waste Manage. Assoc. 2017;67:1000-1011.

31. Koshta V, Patel HR, Chaudhari AR, Shah BP, Patel BM. Use of Biogas as Energy Source: A Review. Int. J. Curr. Microbiol. App. Sci. 2019;8:1540-1547.

32. Granada CE, Hasan C, Marder M, et al. Biogas from slaughterhouse wastewater anaerobic digestion is driven by the arch- 
aeal family Methanobacteriaceae and bacterial families Porphyromonadaceae and Tissierellaceae. Renew. Energy 2018;118:840-846.

33. Huber B, Herzog B, Drewes JE, Koch K, Müller E. Characterization of sulfur oxidizing bacteria related to biogenic sulfuric acid corrosion in sludge digesters. BMC Microbiology 2016;16:Article 153.

34. Lens P. Sulfur cycle. In: Schaechter M, ed. Encyclopedia of Microbiology. Cambridge: Academic Press; 2009. p. 361-369.

35. Kumar S. Acid Rain-The Major Cause of Pollution: Its Causes, Effects. Int. J. Appl. Chem. 2017;13:53-58.

36. Ramirez M. Special Issue Advances in Biogas Desulfurization. Chem. Eng. 2020;4:17.

37. Khoshnevisan B, Tsapekos P, Alfaro N, et al. A review on prospects and challenges of biological $\mathrm{H}_{2} \mathrm{~S}$ removal from biogas with focus on biotrickling filtration and microaerobic desulfurization. Biofuel Res. J. 2017;16:741-750.

38. Xiao C, Ma Y, Ji D, Zang L. Review of desulfurization process for biogas purification. IOP Conf. Ser.: Earth Environ. Sci. 2017;100-012177.

39. Huerta-Reynoso EA, Lopez-Aguilar HA, Gomez JA, Gomez-Mendez MG, Perez-Hernandez A. Biogas power energy production from a life cycle thinking. In: Petrillo A, De Felice F, eds. New frontiers on life cycle assessment - Theory and application. IntechOpen; 2019.

40. Whiting A, Azapagic A. Life cycle environmental impacts of generating electricity and heat from biogas produced by anaerobic digestion. Energy 2014;70:181-193.

41. Aryal N, Kvist T. Alternative of biogas injection into the Danish gas grid system - A study from demand perspective. ChemEngineering 2018;2:43.

42. Hoo PY, Patrizio P, Leduc S, et al. Optimal biomethane injection into natural gas grid-biogas from palm oil mill effluent (POME) in Malaysia. Energy Procedia 2017;105:562-569.

43. Lyng KA, Brekke A. Environmental life cycle assessment of biogas as a fuel for transport compared with alternative fuels. Energies 2019;12:532.

44. Eriksson P, Olsson M. The potential of biogas as vehicle fuel in Europe - A technological innovation systems analysis of the emerging bio-methane technology [report No. 2007:6]. Gothenburg: Chalmers University of Technology; 2007.

45. Li G, Luo K, Shi D. Key technologies, engineering management and important suggestions of shale oil/gas development: Case study of a Duvernay shale project in Western Canada Sedimentary Basin. Petrol. Explor. Develop. 2020;47:791-802.

46. Solarin SA, Gil-Alana LA, Lafuente C. An investigation of long-range reliance on shale oil and shale gas production in the U.S. market. Energy 2020;195:116933.

47. IRENA (International Renewable Energy Agency). Future of Solar Photovoltaic: Deployment, investment, technology, grid integration and socio-economic aspects [report]. Abu Dhabi: IRENA; 2019.

48. Kost C, Shammugam S, Julch V, Nguyen HT, Schlegl T. Fraunhofer ISE: Levelized Cost of Electricity: Renewable Energy Technologies [Internet]. Freiburg: Fraunhofer Institute for Solar Energy Systems; March 2018. Available from: https:/www.ise. fraunhofer.de/en/publications/studies/cost-of-electricity.html
49. KC S, Lutz W. The human core of the shared socioeconomic pathways: population scenarios by age, sex and level of education for all countries to 2100. Global Environ. Change 2017;42:181-192.

50. Ezeh AC, Bongaarts J, Mberu B. Global population trends and policy options. Lancet 2012;380:142-148.

51. Matassa S, Batstone DJ, Hulsen T, Schnoor J, Verstraete W. Can direct conversion of used nitrogen to new feed and protein help feed the world?. Environ. Sci. Technol. 2015a;49:5247-5254.

52. Boland MJ, Rae AN, Vereijken JM, et al. The future supply of animal-derived protein for human consumption. Trends Food Sci. Technol. 2013;29:62-73.

53. Rasouli Z, Valverde-Pérez B, D’Este M, De Francisci D, Angelidaki I. Nutrient recovery from industrial wastewater as single cell protein by a co-culture of green microalgae and methanotrophs. Biochem. Eng. J. 2018;134:129-135.

54. Matassa S, Boon N, Pikaar I, Verstraete W. Microbial protein: future sustainable food supply route with low environmental footprint. Microb. Biotechnol. 2016a;9:568-575.

55. Baligar VC, Fageria NK, He ZL. Nutrient use efficiency in plants. Commun. Soil Sci. Plant Anal. 2001;32:921-950.

56. Foley JA, Ramankutty N, Brauman KA. Solutions for a cultivated planet. Nature 2011;478:337-342.

57. Valverde-Pérez B, Xing W, Zachariae AA, et al. Cultivation of methanotrophic bacteria in a novel bubble-free membrane bioreactor for microbial protein production. Bioresour. Technol. 2020;310:123388.

58. Sillman J, Nygren L, Kahiluoto H, et al. Bacterial protein for food and feed generated via renewable energy and direct air capture of $\mathrm{CO}_{2}$ : Can it reduce land and water use?. Global Food Secur. 2019;22:25-32.

59. Yang A, Zhang G, Meng F, Lu P, Wang X, Peng M. Enhancing protein to extremely high content in photosynthetic bacteria during biogas slurry treatment. Bioresour. Technol. 2017;245: 1277-1281.

60. Ritala A, Häkkinen ST, Toivari M, Wiebe MG. Single Cell Protein: State-of-the-Art, Industrial Landscape and Patents 2001-2016. Front. Microbiol. 2017;8:2009.

61. SchØyen HF, Svihus B, Storebakken T, Skrede A. Bacterial protein meal produced on natural gas replacing soybean meal or fish meal in broiler chicken diets. Arch. Anim. Nut. 2007;61:276-291.

62. Yazdian F, Hajizadeh S, Shojaosadati SA, Khalilzadeh R, Jahanshahi M, Nosrati M. Production of single cell protein from natural gas: Parameter optimization and RNA evaluation. Iran. J. Biotechnol. 2005;3:235-242.

63. Khadijah Hanim AR, Jamilah H, Zakaria Z. Bioproteins production from palm oil agro-industrial wastes by Aspergillus terreus UniMAP AA-1. Pertanika J. Trop. Agric. Sci. 2016;39: 30-40.

64. Bacha U, Nasir M, Khalique A, Anjum AA, Jabbar MA. Comparative assessment of various argo-industrial wastes for Saccharomyces cerevisiae biomass production and its quality evaluation as single cell protein. J. Anim. Plant Sci. 2011;21: 844-849.

65. Pandey A, Soccol CR, Nigam P, Soccol VT, Vandenberghe LPS, Mohan R. Biotechnological potential of agro-industrial residues 
II: cassava bagasse. Bioresour. Technol. 2000;74:81-87.

66. Acosta N, Sakarika M, Kerckhof FM, Law CKY, De Vrieze J, Rabaey K. Microbial protein production from methane via electrochemical biogas upgrading. Chem. Eng. J. 2020;391:123625.

67. Kalyuzhnaya MG. Methane biocatalysis: selecting the right microbe. In: Eckert C, Trinh CT, eds. Biotechnology for biofuel production and optimization. Amsterdam: Elsevier Science and; 2016. p. 353-383.

68. Zha X, Tsapekos P, Zhu X, Khoshnevisan B, Lu X, Angelidaki I. Bioconversion of wastewater to single cell protein by methanotrophic bacteria. Bioresour. Technol. 2021;320:124351.

69. Tsapekos P, Khoshnevisan B, Zhu X, Zha X, Angelidaki I. Methane oxidising bacteria to upcycle effluent streams from anaerobic digestion of municipal biowaste. J. Environ. Manage. 2019;251:109590.

70. Khoshnevisan B, Tsapekos P, Zhang Y, Valverde-Pérez B, Angelidaki I. Urban biowaste valorization by coupling anaerobic digestion and single cell protein production. Bioresour. Technol. 2019;290:121743.

71. Roberts N, Hilliard M, He QP, Wang J. A microalgae-methanotroph coculture is a promising platform for fuels and chemical production from wastewater. Front. Energy Res. 2020;8:563352.

72. Badr K, Hilliard M, Roberts N, He QP, Wang, J. Photoautotroph-methanotroph coculture-A flexible platform for efficient biological $\mathrm{CO}_{2}-\mathrm{CH}_{4}$ co-culture. IFAC PapersOnLine 2019;52:916-921.

73. van der Ha D, Nachtergaele L, Kerckhof FM, et al. Conversion of biogas to bioproducts by algae and methane oxidizing bacteria. Environ. Sci. Technol. 2012;46:13425-13431.

74. Rudravaram R, Chandel AK, Rao LV, Hui YZ, Ravindra P. Bio (single cell) protein: issues of production, toxins and commercialisation status. In: Ashworth, G.S., Azevedo, P., eds. Agricultural wastes. New York: Nova Science Pub Inc.; 2009. p. 129-153.

75. Badr K, Whelan W, He QP, Wang J. Fast and easy quantitative characterization of methanotroph-photoautotroph cocultures. Biotechnol. Bioeng. 2021;118:703-714.

76. Hill EA, Chrisler WB, Beliaev AS, Bernstein HC. A flexible microbial co-culture platform for simultaneous utilization of methane and carbon dioxide from gas feedstocks. Bioresour. Technol. 2017;228:250-256.

77. Xu M, Zhou H, Yang X, Angelidaki I, Zhang Y. Sulfide restrains the growth of Methylocapsa acidiphila converting renewable biogas to single cell protein. Water Res. 2020;184:116138.

78. Dou J, Huang Y, Ren H, et al. Autotrophic, heterotrophic, and mixotrophic nitrogen assimilation for single-cell protein production by two hydrogen-oxidizing bacterial strains. Appl. Biochem. Biotechnol. 2019;187:338-351.

79. Matassa S, Verstraete W, Pikaar I, Boon N. Autotrophic nitrogen assimilation and carbon capture for microbial protein production by a novel enrichment of hydrogen-oxidizing bacteria. Water Res. 2016b;101:137-146.

80. Repaske R. Characteristics of hydrogen bacteria. Biotechnol Bioeng. 1966;8:217-235.

81. Aragno M, Schlegel HG. Physiological characterization of the hydrogen bacterium Aquaspirillum autotrophicum. Arch.
Microbiol. 1978;116:221-229.

82. Volova TG, Barashkov VA. Characteristics of proteins synthesized by hydrogen-oxidizing microorganisms. Appl. Biochem. Microbiol. 2010;46:574-579.

83. Matassa S, Boon N, Verstraete W. Resource recovery from used water: The manufacturing abilities of hydrogen-oxidizing bacteria. Water Res. 2015b;68:467-478.

84. Wainaina S, Lukitawesa, Awasthi MK, Taherzadeh MJ. Bioengineering of anaerobic digestion for volatile fatty acids, hydrogen or methane production: A critical review. Bioengineered 2019;10:437-458.

85. Xia A, Murphy JD. Microalgal cultivationin treating liquid digestate from biogas systems. Trends Biotechnol. 2016;34:264-275.

86. Barua S, Zakaria BS, Chung T, et al. Microbial electrolysis followed by chemical precipitation for effective nutrients recovery from digested sludge centrate in WWTPs. Chem. Eng. J. 2019;361:256-265.

87. Tan XB, Zhang YL, Yang LB, Chu HQ, Guo J. Outdoor cultures of Chlorella pyrenoidosa in the effluent of anaerobically digested activated sludge: The effects of $\mathrm{pH}$ and free ammonia. Bioresour. Technol. 2016;200:606-615.

88. Podevin M, Fotidis IA, De Francisci D, Møller P, Angelidaki I. Detailing the start-up and microalgal growth performance of a full-scale photobioreactor operated with bioindustrial wastewater. Algal Res. 2017;25:101-108.

89. Verbeeck K, De Vrieze J, Pikaar I, Verstraete W, Rabaey K. Assessing the potential for up-cycling recovered resources from anaerobic digestion through microbial protein production. Microb. Biotechnol. 2020;0:1-14.

90. Stiles WAV, Styles D, Chapman SP, et al. Using microalgae in the circular economy to valorise anaerobic digestate: challenges and opportunities. Bioresour. Technol. 2018;267:732-742.

91. Matassa S, Papirio S, Pikaar I, et al. Upcycling of biowaste carbon and nutrients in line with consumer confidence: the "full gas" route to single cell protein. Green Chem. 2020;22:4912-4929.

92. Øverland M, Tauson AH, Shearer K, Skrede A. Evaluation of methane-utilising bacteria products as feed ingredients for monogastric animals. Arch. Anim. Nut. 2010;64:171-189.

93. Aas TS, Grisdale-Helland B, Terjesen BF, Helland SJ. Improved growth and nutrient utilisation in Atlantic salmon (Salmo salar) fed diets containing a bacterial protein meal. Aquacult. 2006;259:365-376.

94. Nangul A, Bhatia R. Microorganisms: A marvelous source of single cell proteins. J. Microbiol. Biotechnol. Food Sci. 2013;3:15-18.

95. Nasseri AT, Rasoul-Amini S, Morowvat MH, Ghasemi Y. Single cell protein: Production and process. Am. J. Food Technol. 2011;6:103-116.

96. Calloway DH. The place of single cell protein in man's diet. In: Davis P, ed. Single cell protein. New York: Academic Press; 1974. p. 129-46.

97. Srividya AR, Vishnuvarthan VJ, Murugappan M, Dahake PG. Single cell protein - A review. Int. J. Pharm. Res. Scholars 2013;2:472-485.

98. Solomons GL. Single cell protein. CRC Crit. Rev. Biotechnol. 1983;1:21-58 
99. Shacklady CA. SCP from hydrocarbons as animal feed ingredients. Process Biochem. 1974;9:9-14.

100. de Groot AP. Minimal tests necessary to evaluate the nutritional qualities and the safety of SCP. In: Davies P, ed. Single Cell Protein. New York: Academic Press; 1974. p. 75-92.

101. Stringer DA. Safety and nutrition testing of single-cell protein. In: Wagner F, ed. Symposium Mikrobielle Proteingewinnung. Weinheim: Verlag Chemie; 1975. p. 167-172.

102. Scrimshaw NS. Single cell protein for human consumption: An overview. In: Tannenbaum SR, Wang DIC, eds. Single cell protein II. Cambridge: MIT Press; 1975. p. 24-45.

103. Goldberg I. Single cell protein. $1^{\text {st }}$ ed. Berlin/Heidelberg: Springer-Verlag; 1985. p. 148-152.

104. Scrimshaw NS, Murray EB. Nutritional Value and Safety of Single Cell Protein. In: Rehm HJ, Reed G, Mihler A, Stadler P, eds. Biotechnology (Enzymes, Biomass, Food and Feed). Weinheim: VCH Verlagsgesellschaft mbH; 1995. p. 221-237.

105. Scrimshaw NS, Dillon JC. Allergic Responses to Some Single-cell Proteins in Human Subjects. In: Garattini S, Paglialunga S, Scrimshaw N, eds. Single cell protein safety for animal and human feeding. Oxford: Pergamon Press Ltd.; 1979. p. 171-178.

106. Eastham EJ. Clinical Gastrointestinal Allergy. In: Garattini S, Paglialunga S, Scrimshaw N, eds. Single cell protein safety for animal and human feeding. Oxford: Pergamon Press Ltd.; 1979. p. 179-185.

107. Solomons GL. Microbial proteins and regulatory clearance for RHM myco-protein. In: Moo-Young M, Gregory KF, eds. Microbial Biomass Proteins. London: Elsevier Applied Science; 1986. p. 19-26.

108. Salehi R, Chaiprapat S. Single-/triple-stage biotrickling filter treating a $\mathrm{H}_{2} \mathrm{~S}$-rich biogas stream: Statistical analysis of the effect of empty bed retention time and liquid recirculation velocity. J. Air Waste Manage. Assoc. 2019;69:1429-1437.

109. Angelidaki I, Treu L, Tsapekos P, et al. Biogas upgrading and utilization: current status and perspectives. Biotechnol. Adv. 2018;36:452-466.

110. Okoro OV, Sun Z. Desulphurisation of biogas: A systematic qualitative and economic-based quantitative review of alternative strategies. Chem. Eng. 2019;3:76.

111. Roode-Gutzmer QI, Kaiser D, Bertau M. Renewable methanol synthesis. ChemBioEng Rev. 2019;6:209-236.

112. Offermanns H, Plass L, Heyde R. Methanol in industrial chemistry (general). In: Bertau M, Offermanns H, Plass L, Schmidt F, Wernicke HJ, eds. Methanol: The Basic Chemical and Energy Feedstock of the Future. Berlin: Springer; 2014. p. 13-18.

113. EI-Zeftawy AM. Focus on the Chemical value of methanol. J. King Saud Univ. 1995;7:209-256.

114. Shamsul NS, Kamarudin SK, Rahman NA, Kofli NT. An overview on the production of bio-methanol as potential renewable energy. Renew. Sust. Energy Rev. 2014;33:578-588.

115. Kim I, Yoo YS, Yoon YH, et al. Bio-methanol production using treated domestic wastewater with mixed methanotroph species and anaerobic digester biogas. Water 2018;10:1414.

116. Riaz A, Zahedi G, Klemes JJ. A review of cleaner production methods for the manufacture of methanol. J. Cleaner Prod. 2013;57:19-37.
117. Patel SKS, Mardina P, Kim D, et al. Improvement in methanol production by regulating the composition of synthetic gas mixture and raw biogas. Bioresour. Technol. 2016a;218: 202-208.

118. Fei Q, Guarnieri MT, Tao L, Laurens LML, Dowe N, Pienkos PT. Bioconversion of natural gas to liquid fuel: Opportunities and challenges. Biotechnol. Adv. 2014;32:596-614.

119. Xin JY, Zhang YX, Zhang S, Xia CG, Li SB. Methanol production from $\mathrm{CO}_{2}$ by resting cells of the methanotrophic bacterium Methylosinus trichosporium IMV 3011. J. Basic Microbiol. 2007;47:426-435.

120. Khmelenina VN, Murrell JC, Smith TJ, Trotsenko YA. Physiology and biochemistry of the aerobic methanotrophs. In: Rojo F, ed. Aerobic utilization of hydrocarbons, oils and lipids. Cham: Springer; 2018. p. 1-25.

121. Xin JY, Cui JR, Niu JZ, et al. Biosynthesis of methanol from $\mathrm{CO}_{2}$ and $\mathrm{CH}_{4}$ by methanotrophic bacteria. Biotechnol. 2004;3:67-71.

122. Alsayed A, Fergala A, Eldyasti A. Sustainable biogas mitigation and value-added resources recovery using methanotrophs intergrated into wastewater treatment plants. Rev. Environ. Sci. Biotechnol. 2018;17:351-393.

123. Kalyuzhnaya MG, Puri AW, Lidstrom ME. Metabolic engineering in methanotrophic bacteria. Metab. Eng. 2015;29:142-152.

124. Chistoserdova L, Vorholt JA, Lidstrom ME. A genomic view of methane oxidation by aerobic bacteria and anaerobic archaea. Genome Biol. 2005;6:208.

125. Zhang W, Ge X, Li YF, Yu Z, Li Y. Isolation of a methanotroph from a hydrogen sulfide-rich anaerobic digester for methanol production from biogas. Process Biochem. 2016;51:838-844.

126. Ge X, Yang L, Sheets JP, Yu Z, Li Y. Biological conversion of methane to liquid fuels: Status and opportunities. Biotechnol. Adv. 2014;32:1460-1475.

127. Park SY, Kim CG. Application and development of methanotrophs in environmental engineering. J. Mater. Cycles Waste Manage. 2019;21:415-422.

128. Patel SKS, Kumar V, Mardina P, et al. Methanol production from simulated biogas mixtures by co-immobilized Methylomonas methanica and Methylocella tundra. Bioresour. Technol. 2018a;263:25-32.

129. Suhad SH. Potential application and performance of methanotrophic mixed culture under mainstream condition in wastewater treatment plant [dissertation]. Toronto: York University; 2019.

130. Sheets JP, Ge X, Li YF, Yu Z, Li Y. Biological conversion of biogas to methanol using methanotrophs isolated from solid-state anaerobic digestate. Bioresour. Technol. 2016;201: 50-57.

131. Alsayed A. Biological conversion process of methane into methanol using mixed culture methanotrophic bacteria enriched from activated sludge system [dissertation]. Toronto: York University; 2017.

132. Patel SKS, Mardina P, Kim SY, Lee JK, Kim IW. Biological methanol production by a type II methanotroph Methylocystis bryophila. J. Microbiol. Biotechnol. 2016b;26:717-724.

133. Sheets JP, Lawson K, Ge X, Wang L, Yu Z, Li Y. Development and evaluation of a trickle bed bioreactor for enhanced mass 
transfer and methanol production from biogas. Biochem. Eng. J. 2017;122:103-114.

134. Kondaveeti S, Patel SKS, Pagolu R, et al. Conversion of simulated biogas to electricity: Sequential operation of methanotrophic reactor effluents in microbial fuel cell. Energy 2019;189:116309.

135. Mardina P, Li J, Patel SKS, Kim IW, Lee JK, Selvaraj C. Potential of immobilized whole-cell Methylocella tundrae as a biocatalyst for methanol production from methane. J. Microbiol. Biotechnol. 2016;26:1234-1241.

136. Patel SKS, Kondaveeti S, Otari SV, et al. Repeated batch methanol production from a simulated biogas mixture using immobilized Methylocystis bryophila. Energy 2018b;145:477-485.

137. Patel SKS, Shanmugam R, Kalia VC, Lee JK. Methanol production by polymer-encapsulated methanotrophs from simulated biogas in the presence of methane vector. Bioresour. Technol. 2020a;304:123022.

138. Su Z, Ge X, Zhang W, Wang L, Yu Z, Li Y. Methanol production from biogas with a thermostolerant methanotrophic consortium isolated from an anaerobic digestion system. Energy Fuels 2017;31:2970-2975.

139. Yoo YS, Han JS, Ahn CM, Kim CG. Comparative enzyme inhibitive methanol production by Methylosinus sporium from simulated biogas. Environ. Technol. 2015;36:983-991.

140. Henard CA, Franklin TG, Youhenna B, et al. Biogas bio- catalysis: Methanotrophic bacterial cultivation, metabolite profiling, and bioconversion to lactic acid. Front. Microbiol. 2018;9:2610.

141. Eun-Hee L, Yi T, Moon KE, Park H, Ryu HW, Cho KS. Characterization of methane oxidation by a methanotroph isolated from a landfill cover soil, South Korea. J. Microbiol. Biotechnol. 2011;21:753-756.

142. Caceres M, Gentina JC, Aroca G. Oxidation of methane by Methylomicrobium album and Methylocystis sp. in the presence of $\mathrm{H}_{2} \mathrm{~S}$ and $\mathrm{NH}_{3}$. Biotechnol. Lett. 2014;36:69-74.

143. Ge X, Yang L, Xu J. Cell Immobilization: Fundamentals, technologies, and applications. In: Wittmann C, Liao JC, eds. Industrial biotechnology: Products and processes. Weinheim: Wiley-VCH Verlag GmbH \& Co. KGaA; 2016. p. 205-235.

144. Kourkoutas Y, Bekatorou A, Banat IM, Marchant R, Koutinas AA. Immobilization technologies and support materials suitable in alcohol beverages production: a review. Food Microbiol. 2004;21:377-397.

145. Patel SKS, Gupta RK, Kondaveeti S, et al. Conversion of biogas to methanol by methanotrophs immobilized on chemically modified chitosan. Bioresour. Technol. 2020b;315:123791.

146. Patel SKS, Selvaraj C, Mardina P, et al. Enhancement of methanol production from synthetic gas mixture by Methylosinus sporium through covalent immobilization. Appl. Energy 2016c;171:383-391. 